\title{
Effects of Sand Mining on Planetary Health: A Case Study of Ulashi River, Okija Anambra State, Nigeria
}

\author{
Akanwa A0* \\ Department of Environmental Management, Chukwuemeka Odumegwu Ojukwu University, \\ Uli Campus, Anambra State, Nigeria
}

*Corresponding author: Angela Akanwa, Chukwuemeka Odumegwu Ojukwu University, Anambra State, Chukwuemeka Odumegwu Ojujwu University, Uli Campus, PMB 02, Anambra

\section{Research article}

Volume 4 Issue 3

Received Date: March 19, 2020

Published Date: April 13, 2020

DOI: $10.23880 /$ jenr-16000198

State, Nigeria, Tel: +234 8065813 596; Email: angela.akanwa1@gmail.com

\section{Abstract}

Globally, small scale mining has been recognized as a major contributor to mineral production, employment, poverty alleviation, public revenue and rural development. However, the unsustainable means of resource extraction has become an environmental concern in global South. This study investigated sand mining and its effects on Ulashi River, surrounding farmlands and attendant health risks in Okija, Ihiala LGA, Anambra State. The concept of planetary health was used as a lens to examine the effects of sand mining on the environment and a pathway to address the eco-health inequalities to the vulnerable community. A mixed method approach was adopted in the case study that included qualitative (key informant interviews, field observations and photography) and quantitative methods (81 questionnaires were randomly administered to residents). Laboratory analysis was used to determine the physiochemical parameters and heavy metals $(\mathrm{Pb}, \mathrm{Mn}$ and $\mathrm{Zn})$ sampled from Ulashi River. Findings from the study showed that an estimated 33,235 $\mathrm{m} 3$ of sands have been removed from Ulashi River for the past 17 years. Also, the negative effects of mining in Ulashi River include loss of river bank vegetation, erosion, changes on the river system and lowered riverbed; effects of mining on land include loss of tree population and unquantifiable plant species. Analysed water samples showed that $\mathrm{pH}$, turbidity, DO, BOD, COD and heavy metals ( $\mathrm{Pb}$ and $\mathrm{Mn}$ ) were above the permissible limits of NESERA/WHO, hence, Ulashi River is contaminated and community health is endangered when water is used for domestic uses without treatment. Linear Regression was used to test the economic benefits of sand mining. Results indicated that for every unit increase in monthly number of sands extracted from Ulashi River, it is estimated that the monthly income level of the respondent will increase by 0.317 units. Hence, sand mining has a significant relationship with the economic livelihood of the community. This study recommended youth partnership and education, enforcement of policies, monitoring environmental quality and community inclusion in research studies.

Keywords: Planetary health, Sand mining, Ulashi River, Sand loss, Vegetation loss, Youth inclusion

\section{Introduction}

The growing world population and the need to expand city suburbs and towns to accommodate the increasing housing needs and infrastructural demands have escalated the demand for sand extraction. It was estimated that the overall extraction of sand was 40 billion tones annually, so that every person on the planet uses 18 kilograms of sand daily $[1,2]$.

Nigeria is at the verge of a population explosion and projections have been made that the population of Nigeria will be 398 million by 2050, which will make it the world's third largest country. The large population growth will 


\section{Journal of Ecology and Natural Resources}

definitely put pressure on sand consumption as urban and rural areas keep expanding, considering that, Nigeria has vast natural resources particularly large sand deposits [3].

The consumption levels of sands have increased tremendously since sands make up the foundational raw material used for developing the world cities and infrastructure. China in 2011 and 2013, consumed 6.6 gigatons of concrete which is more than the United States which used 4.5 gigatons between 1901 and 2000 in the entire $20^{\text {th }}$ century [4]. Many countries such as Indonesia, Dubai, India, Singapore, among others have increased their demand for extracted sand and globally sands are removed three times, yearly from all rivers and glaciers, more than they can be naturally replaced $[1,5]$. At this rate, it is estimated that the total annual demand for sand and aggregates will rise to 60 gigaton by 2030 [6].

Informal mining industries that include but not limited to sand mining have brought economic growth and employment opportunities to both wealthy and poor regions; hence it has become a means of livelihood to thousands [7]. According to World Bank [8] small scale mining industry has employed 40 million people worldwide and in Africa estimates accounts for 9 million people and at least a further 60 million are reliant on this industry and this makes it the largest mining workforce.

Unfortunately, in spite of this economic contribution, the mining processes in developing regions are unsustainable. They are void of technical criteria such as geotechnical surveys and professionalism thereby, creating diverse environmental problems. There are enormous negative impacts associated with sand mining that have raised environmental concerns on vegetation loss, damage of water bodies, and decline in plants and aquatic life and health issues in Nigeria and Global South countries. Examples of some affected countries include, but are not limited to Nigeria, India, Ethiopia, Cambodia, Vietnam, Singapore, Nairobi, Malaysia, Jamaica, Indonesia, Philippines, South Africa, among others [9-15].

According to Nwajide, et al. [16] the geology of Anambra State, where the study area is located, supports rich soil deposits derived from the underlying sandstone and shale units. This makes granite, clay, kaolin and sands abundant in the State. This facilitates mineral exploitation which is used for diverse purposes. Okija is a growing town located in Ihiala Local Government Area, Anambra State, and Southeastern Nigeria. It has a growing population, which from 23, 311 in 2006 [17], at $3.2 \%$ annual growth rate, is estimated to be over 87,796 persons in 2020 .

The natural deposits of sand resources both on land and in-stream in Okija have facilitated sand mining activities.
This has brought immense socio-economic advantages, though it has left major huge environmental degradation in Anambra State, especially on its rainforest. Clearly, the growing population coupled with the abundance of sands has triggered high sand consumption levels, thereby negatively transforming its rich vegetation with changes that also threaten the quality of Ulashi River.

From the foregoing, the economic contributions of sand mining in Anambra State are notable though their environmental consequence is a huge concern. There is need for environmentally friendly approaches to sand mining that should have minimal negative impacts on environmental quality and community health. To achieve sustainable sand mining operations in Okija lies in the framework provided by the concept of planetary health which integrates environment policies into development strategies $[18,19]$. It is a sustainable concept that informs human actions such as mining that have negative impacts on the environment should undergo systematic environmental and scientific impact assessments before, during and after mining to ensure remediation and quality control/maintenance of lands and rivers after mine closure.

\section{Statement of Problem}

The spread of natural resources in Anambra State coupled with the rural development and extensive construction works has prompted mineral exploration especially sand excavation both on land and in river systems. Ulashi is also known as Urashi or Orashi is of the lower Niger River basin, a $205 \mathrm{~km}$ in length and a tributary of Oguta Lake in southeastern Nigeria [20,21]. The Upper Ulashi River catchment takes off $183 \mathrm{~m}$ above mean sea level from Dikenafai (latitude $05^{\circ} 45^{\prime} \mathrm{N}$, longitude $07^{\circ} 10^{\prime} \mathrm{E}$ ) and ends at the river crossing of the Onitsha -Owerri Road at Okija in Ihiala LGA of Anambra State $[20,22]$. The river serves as a means of transportation and also it is used for drinking and other domestic activities [23].

The soils are ferrallitic- made up of deep porous sandy loams/loamy sand with clay content [3]. The rich-soil deposits on land are voluminous and also alluvial soils are carried and deposited at Ulashi River bank during overflows. These make the sands suitable for concrete and construction works and hence trigger sand extraction. Ulashi and its environs are located within the rainforest characterized by abundance of plant species, sometimes exceeding 150 different species per hectare [24]. Unfortunately, sand excavation activities is a threat to the robust rainforest resource since sand extraction in Ulashi River and its environs are largely informal and small scaled.

The unsustainable approach to mining operations and 


\section{Journal of Ecology and Natural Resources}

the volume of sands removed has a negative impact on land, vegetation cover, river system and even health risks. Sand mining results in the loss of lands, water table is lowered and decreased quantity of sand supplies, water turbidity, siltation and biodiversity are affected. Despite these negative impacts, sand is continually mined and serves as a source of livelihood to residents; moreover, available data quantifying vegetation clearance and its impacts in Okija and Ulashi River is lacking and hence, this study takes recognisance of these gaps in literature added that it can hinder environmental sustainability and policy enforcement towards sustainable natural resource extraction.

It is the need to investigate sand mining activities in Okija and its consequences on Ulashi River, vegetation/lands and health risks that has informed these pertinent questions:

i. What is the extent of sand mining and its economic contribution to the community?

ii. What are the effects of sand mining on Ulashi River and the environment?

iii. What are the sustainable solutions to sand exploration in Okija?

\section{Planetary Health Concept}

Planetary health concept stems from the environmental and holistic health movements of the 1970-80s that sought the interconnections between the health of a person and place at all scales. It created the link between humandriven changes to the planet and their consequences with developed sustainable solutions to the identified challenges $[25,26]$. As an emerging interdisciplinary field [27], it pursues similar goals that will aid the accomplishment of sustainable development goals especially that which affects this present study "SDG 14 (life below water) and 15 (life on land) by 2030. Planetary health concept characterizes and quantifies human actions or rather human -caused disruptions of earth's natural systems and its implications and viable solutions [28,29]. Human actions such as sand mining can cause mega morphological disturbances that can influence over $80 \%$ of the communicable and noncommunicable diseases worldwide [1,19]. These prevailing issues surrounding sand mining in Okija both on land and in-stream coupled with health risks informed this study.

Indeed, planetary health visualizes that every human action will affect human health at a personal or global level, hence humans become the final targets of environmental pollution. It illustrates the interconnectivity between human health and the health of natural systems/ecosystems such as the social, political, economic and even environmental systems (at all scales). It seeks to maintain economic activities and advancement while protecting the futuristic interests of the environment, which man's health is an integral part as well. Basically, planetary health concept is an environmental movement [30] that share the global ecohealth concerns which include human health, environmental health of ecosystems and enduring sustainable solutions.

\section{Methodology}

\section{Study Area}

The study area lies approximately between latitude

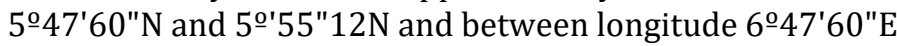
and 6도" 80 (Figure 1).

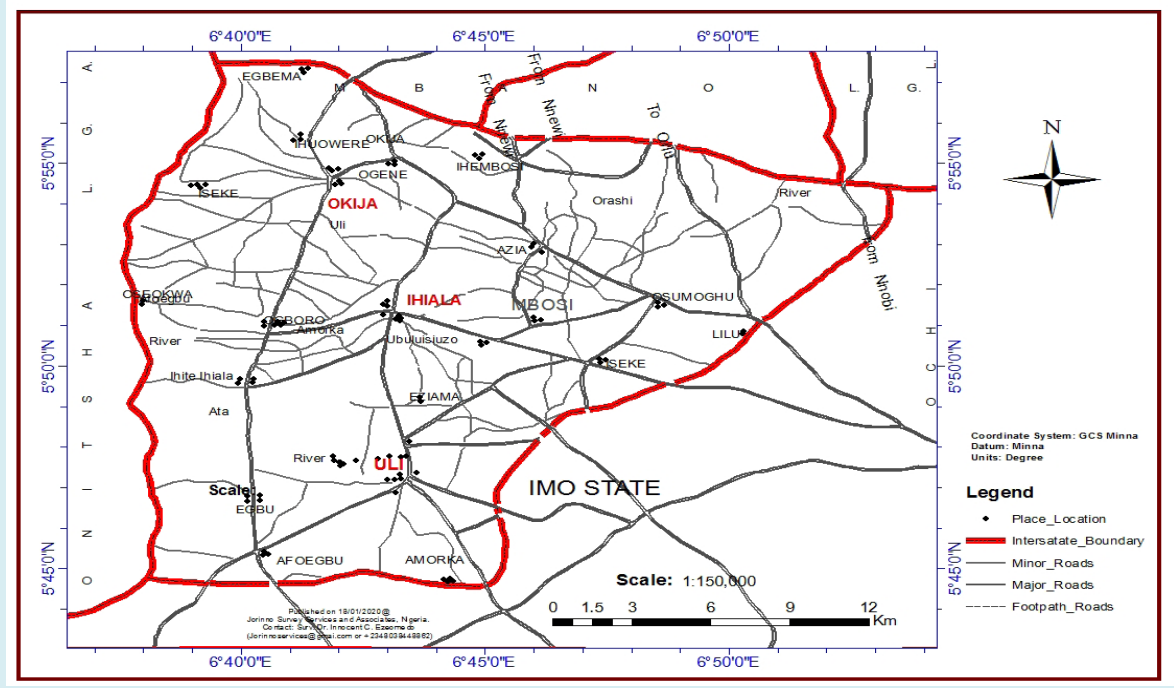

Figure 1: Map of Ihiala Local Government Area showing surrounding communities and the study location. Source: Department of Environment Management. 
Its elevation is 137 meters above sea level and covers an area of 8.6 square kilometres. Its climate is classified as tropical. It has an average daily temperature ranging from $22^{\circ} \mathrm{C}-32^{\circ} \mathrm{C}$. It has an average yearly rainfall of $1500 \mathrm{~mm}$ $[31,32]$. It has two climatic seasons: the wet season which is experienced from the month of April-October and the dry season which is felt from November-March. During the dry season, the influence of the Sahara air mass affects $95 \%$ of the country [33]. The area is made up of plain lands and hills. It has alluvial plains in the west and on the east lies the Awka-Orlu uplands with elevation ranging from 30$80 \mathrm{~m}$ [33]. The inhabitants predominantly engage in mining, peasant agriculture and fishing.

\section{Data Gathering}

A mixed method, case study approach was used to investigate the effects of sand mining in Ulashi River and Okija. Data was gathered from both primary and secondary sources. The primary data included administration of questionnaires to residents living within the study area. In addition, samples from Ulashi River were taken and subjected to laboratory analysis and compared with NESREA and WHO standards for drinking water. Key informant interviews, observation, photography were also fundamental in acquiring information from the study area. Secondary data were sourced from books, relevant articles from journals and World Bank Report on artisanal/small scale mining and effects of sand mining on the environment.

\section{Sampling Technique}

Probability and non-probability sampling methods were used in this study covering purposive, simple random and systematic sampling. However, purposive sampling technique was the dominant technique used in this study. This is because the questionnaires and interview data included different variables of the target population in terms of occupation, socio-economic data of the respondents and interviewees perception towards sand mining and its effects on the environment.

Ubuluisiuzor was selected as the study community based on its proximity to the sand mining site and Ulashi River. Also, purposive sampling was employed to ensure that views of the varied key informants identified with sand mining were chosen and represented. The 15 key informants interviewed include sand miners, truck drivers, sand loaders, contractor, fishermen, bricklayers, river divers, officials at the local government. Others within the locality were also contacted for relevant information. Moreover, there were field observations and photographs to capture the situation at the sand mine and Ulashi River.
Green [34] sample size model "rules-of-thumb" was used to examine the model overall with minimum sample size of $50+8 \mathrm{k}(\mathrm{k}=$ no. of determinants). The number of determinants for the study is 7, giving a sample size of 106 respondents. Simple random sampling technique was applied to sample 106 persons from the projected population with an annual growth rate of 3.2 and 87,796 persons. Systematic random sampling which gave an interval to every fourth household at a random starting point was applied in the selection of household respondents for the administration of structured questionnaires in the community.

The minimum model sample size was used in this study considering that, multiple sources of data were also applied to substantiate questionnaire administration. Other sources of data were meant to safeguard and triangulate the results while representing the real conditions of the study which was not meant to produce generalizable findings. The central tenet of this study was to explore in depth, produce insight and detailed information on sand mining (in stream and land) in Okija. Pinnock, et al. [35] maintained that data collected in different ways should lead to similar conclusions; hence, it develops a holistic picture of the studied phenomenon.

\section{Data Analysis}

A Laboratory test was used to analyse water samples from Urashi River. It involved a two group tests used to compare the group were sand mining was carried out and were it was not (control) along Ulashi River. These groups were compared, differences observed and inferences were drawn based on NESERA/WHO standards. The physiochemical parameters $(\mathrm{pH}$, turbidity, TDS, conductivity, BOD, DO, COD, Nitrate, Chloride, Fluoride and Sulphate) of Urashi River were analysed. The $\mathrm{pH}$ was measured using laboratory $\mathrm{pH}$ meter Hanna model HI991300 [36]; Turbidity by Nephlometric turbidity unit (NTU); TDS using APHA2510 ATDS 139 tester; conductivity using APHA 1998 [36]; BOD was determined by the Respirometric method; dissolved oxygen (DO) content of the samples was determined before and after the incubation; while the heavy metals ( $\mathrm{Pb}, \mathrm{Mn}$ and $\mathrm{Zn}$ ) were analysed using Atomic Absorption Spectrometer (AAS) analysis.

A total of three $(3, A B C)$ water sampling points were taken along Ulashi River with Clean $75 \mathrm{cl}$ plastic bottles rinsed thoroughly (to avoid cross contamination) with water gotten from River before the proper collection of the water sample. Grab samples were collected by dipping the plastic bottles into the River to get a representative fraction of the River.

The samples were stored in an iced cooler to avoid exposure to external factors such as air, light. (Figure) 3 
showed the Ulashi River and the sampling points 1, 2 and 3 (Control). Water samples 1 and 2 (Intense mining activities) were taken at an interval distance of 5metres apart, while the control sample 3(absence of mining activities) was taken 20 metres upstream away from sample 1 and 2 (Figure 2). The control sample was collected upstream in order to analyse its sediment load while samples (1) and (2) were collected from Ulashi River at the points of excessive river mining (downstream). Linear Regression model was applied in the study. Results were interpreted with descriptive statistics such as tables, charts, and percentages.

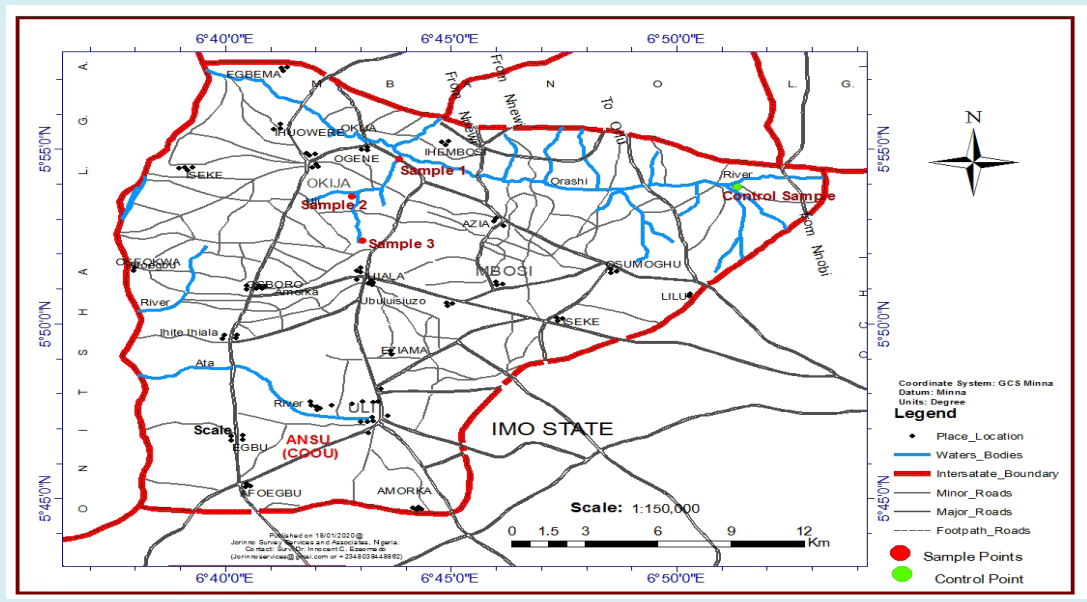

Figure 2: Map of Ihiala Local Government Area showing the study sample points along Urashi River. Source: Department of Environment Management.

\section{Results/Discussion}

The results gathered from questionnaire, regression analysis, laboratory analysis, in-depth interview, observation and photographs were present and discussed. In the course of questionnaire administration twenty five (25) of them were not returned from the field. The socio-economic variables that were measured by questionnaire include sex, age, income, occupational status, education, monthly income and monthly volume of sand transported by tippers. Analysis showed that males were $69.1 \%$ while females were $30.9 \%$. The result showed that men were more in number than females. The reason could be attributed to men representing their families as the leaders based on the demands of AfricanNigerian culture.

The age distribution of the respondents as shown in the bar chart (Figure 3) indicated that respondents between 31-40 years had the largest distribution of $35.8 \%$ while the age range of 61 and above had the lowest number of responses of $7.4 \%$. The age range $21-30$ had a response of $32.1 \%$, while $41-50$ had a response of $16.0 \%$ and age range $51-60$ had a response of $8.6 \%$. This revealed that $67.9 \%$ of $(21-40)$ residents in the area are predominantly young people who were less than 50 years.

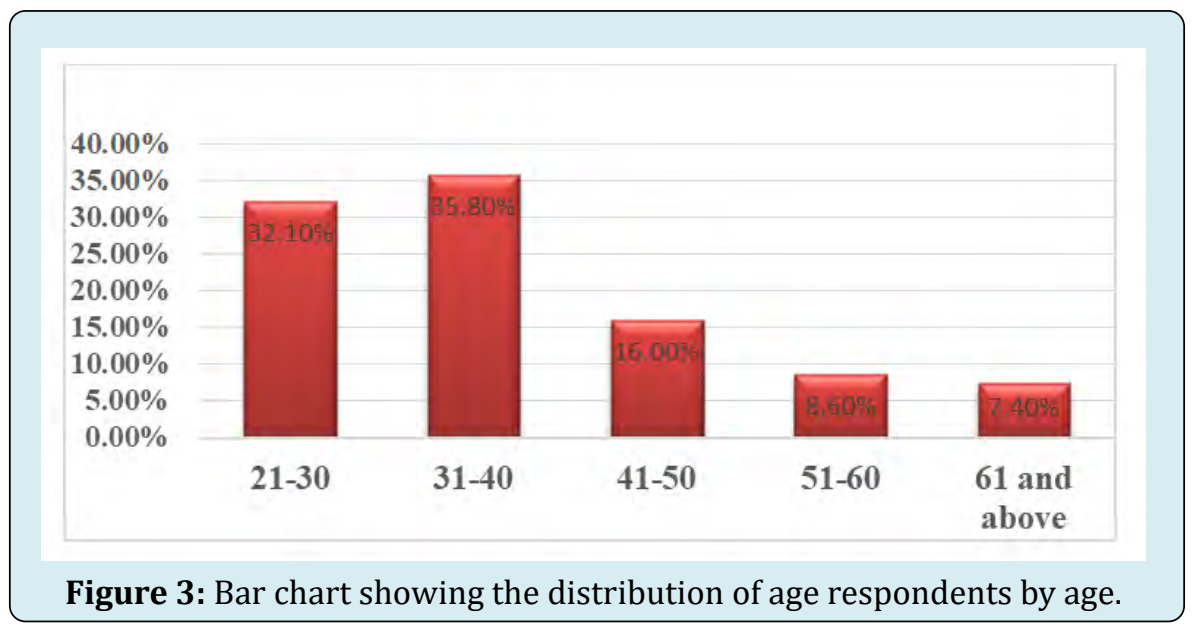


(Table 1) shows the occupational status of the respondents in the study area. The results showed that $39.5 \%$ of the residents were identified with sand mining activities, $(21.0 \%)$ of the populace were farmers. Others include business men/women (19.8\%); civil servants (7.4\%), unskilled labourers (4.9\%), students and artisans share the size of $3.7 \%$ and $3.7 \%$ respectively.

\begin{tabular}{|c|c|c|}
\hline Occupational status & Frequency & Percent \% \\
\hline Sand mining & 32 & 39.5 \\
\hline Farmers & 17 & 21 \\
\hline Business Men/Women & 16 & 19.8 \\
\hline Civil servant & 6 & 7.4 \\
\hline Unskilled labourers & 4 & 4.9 \\
\hline Students & 3 & 3.7 \\
\hline Artisan & 3 & 3.7 \\
\hline Total & 81 & 100 \\
\hline
\end{tabular}

Table 1: Occupational status of respondents

Source: Field work, 2020

(Table 2) shows the education status of the residents of the study area. The table revealed that $46.9 \%$ of the populations have primary education and $35.8 \%$ of the sample population attained secondary education level. Also, $3.7 \%$ and $13.6 \%$ of the sampled population attained tertiary education and informal education respectively. It can be concluded that majority of the study population have only primary school education.

\begin{tabular}{|c|c|c|}
\hline Educational status & Frequency & \% Response \\
\hline Primary education & 38 & 46.9 \\
\hline Secondary education & 29 & 35.8 \\
\hline Tertiary education & 3 & 3.7 \\
\hline Non-formal education & 11 & 13.6 \\
\hline Total & 81 & 100 \\
\hline
\end{tabular}

Table 2: Educational status of respondents.

Source: Field work, 2020

(Table 3) reveals the monthly volume of sand mined and transported by trucks, $2.4 \%$ of the respondents agreed that below 30 trucks of sand are extracted monthly, 9.9\% for 30 - 50 trucks monthly, $17.3 \%$ for $51-70$ trucks monthly, $29.6 \%$ for 71 - 90 trucks monthly, and $40.7 \%$ for 100 trucks and above monthly. This is in consonance with the findings of Gathogo, et al. [37] which revealed that large volumes of sand were extracted from river sand mining in River Kivou in kitui County, Kenya with 8-15 Lorries load every day which is about 50-60tons per day.

\begin{tabular}{|c|c|c|}
\hline Volume of Sands & Frequency & Percent (\%) \\
\hline Below 30 trucks & 2 & 2.4 \\
\hline $30-50$ trucks & 8 & 9.9 \\
\hline $51-70$ trucks & 14 & 17.3 \\
\hline $71-90$ trucks & 24 & 29.6 \\
\hline 100 trucks and above & 33 & 40.7 \\
\hline Total & 81 & 100 \\
\hline
\end{tabular}

Table 3: Monthly Number of Sand transported by Trucks. Source: Field work, 2020

(Table 4) indicates the range of income of the respondents. It showed that $19.8 \%$ of the respondents earned $\$ 80,000$ and above monthly (218.88 USD) while $34.6 \%$ earned about N51-70,000 (191.52USD) and the least earned 13.6\% which is about $\$ 10,000-30,000$ (82.08 USD). The result showed that $\$ 70,000$ (191.52USD) was the highest amount earned by respondents.

\begin{tabular}{|c|c|c|}
\hline Income Distribution & Frequency & Per cent (\%) \\
\hline Below \#10,000 & 12 & 14.8 \\
\hline$\# 10,000-\# 30,000$ & 11 & 13.6 \\
\hline$\# 31,000-\# 50,000$ & 14 & 17.2 \\
\hline$\# 51,000-\# 70,000$ & 28 & 34.6 \\
\hline$\# 80,000$ and Above & 16 & 19.8 \\
\hline Total & 81 & 100 \\
\hline
\end{tabular}

Table 4: Monthly Income level of the respondents.

Source: Field work, 2020

\section{Economic Contribution of Sand Mining to the Community}

Findings from the study showed that majority of the respondents $(69.1 \%)$ were males who were heads that represented their families. This result was supported by Sumani [38] in Danko upper west region of Ghana, where the study was male-dominated. Also, majority of the respondents' were less than 50 years (Figure 3). The predominant young people can be an advantage for environmental interventions in the community targeted towards sustainable sand mining. In addition, the majority of the respondents had at least primary and secondary school education which made communication and transfer of information efficient. However, during in-depth interviews, with truck drivers and sand miners, they added that sand mining was attractive since it required minimum education so most young people can easily get involved in sand mining. They informed that the basic requirement was the operation of machines, physical strength for digging, diving and loading sands into trucks.

The occupation status showed sand mining to be a major $(39.5 \%)$ source of livelihood in the community (Table 1$)$. This 
was shown from the respondents' income levels (34.6\%) earned within (\$51,000-\$70,000) (191.52USD) monthly. It has been noted that small scale mining activities such as sand mining has been globally accepted as a legitimate source of livelihood in developing countries where poverty levels are rising. It was determined that $50 \%$ of Nigerians live below the international poverty line which is 2 USD per day and unemployment rates are peaked at 23.1\% (World Bank, 2018). The economic situation has made informal sand mining a lucrative business in Anambra State [39]. According to Erhun [40], it is a major source of livelihood, employing tens of millions of people.

Also, in order, to further buttress the economic contribution of sand mining in the study area, a regression model was applied. (Tables 5\&6) showed the summary of linear regression analysis and correlation coefficient respectively. This was used to test the relationship between respondents' monthly income levels, Y (dependent) and the monthly volumes of sands extracted, $\mathrm{X}$ (independent) variables. The aim was to find out if there is a positive relationship between increasing incomes and monthly number of sands removed from Ulashi River. The regression model indicated that sand removal will increase income levels of the residents.

\begin{tabular}{|c|c|}
\hline $\mathbf{Y}$ & $\mathbf{X}$ \\
\hline 12 & 2 \\
\hline 11 & 8 \\
\hline 14 & 14 \\
\hline 28 & 24 \\
\hline 16 & 33 \\
\hline
\end{tabular}

Table 5: Linear Regression Analysis

Hence, using linear regression model thus; Regression model:

\subsection{0 .317445}

Interpretation from the regression model showed that for every unit increase in monthly number of sands removed from Ulashi River and transported by trucks, it is therefore estimated that the monthly income level of the respondent will increase by 0.317 units. (Table 5) showed the summary of regression statistics for correlation coefficient.

\begin{tabular}{|c|c|}
\hline \multicolumn{2}{|c|}{ Regression Statistics } \\
\hline Multiple R (correlation coefficent) & 0.573772 \\
\hline R Square (coefficient of determination) & 0.329215 \\
\hline Adjusted R Square & 0.105619 \\
\hline Standard Error & 6.497289 \\
\hline
\end{tabular}

Table 6: Correlation coefficients.
The correlation coefficient is 0.574 based on the linear correlation between two variables, 0.573 indicates that there is a strong linear positive correlation between $\mathrm{X}$ and $\mathrm{Y}$. The adjusted $\mathrm{R}$ square ranges from. The closer $\mathrm{R}^{2}$ is to 1 the higher the linear relationship between $\mathrm{X}$ and $\mathrm{Y}$. Conclusions from the linear regression analysis and the correlation coefficients showed that there is a high linear relationship between the extracted sands from Ulashi River and the increased income levels of respondents in Okija people.

In addition, the sand miners/bricklayers and other men interviewed added that mining business created opportunities for them to increase their income levels since the primary education they had could not get them government jobs. Also, most of the interviewees maintained that apart from the income earned from sand mining, they were also able to create other jobs related to sand mining as well. The river divers interviewed also confirmed that, apart from harvesting sands from Ulashi River, they were also involved in selling sands, bricklaying and moulding of blocks. This showed that the sand mining was a major source of livelihood that aided in community diversification of skills and also increased their earning capacity directly or indirectly. One of the sand miners reported that:

Sand mining is a source of income for me and my family considering the economic hardship in the country. I earn enough to take care of my wife and two children. It has also helped me to learn the skill of plastering. So that I can get contracts of supplying sands and also plaster buildings as well.

The community elder and other men interviewed maintained that community mining in Okija has contributed to the development of the town through direct employment opportunities for indigenes mostly youths as loaders, diggers and miners. Also, it has made the supply of sands for construction works available and affordable for rural development and individuals to build houses with high preference for river sands. The community elder indicated that river mining is a lucrative business because:

The Ulashi River provides the quality of sand we need within our community and beyond for building. We prefer sands from riverbanks because of its ability to bind well in concrete and it pays us more money than sand from land. This makes river sand mining preferred by miners and buyers.

This statement revealed why there is demand for sands from Ulashi River based on the nature and its preference for building and also the economic benefits and livelihood opportunities it offers to residents. The results from administered questionnaires, key informant interviews and regression tests confirmed that sand mining has generated jobs; livelihood and more importantly diversified their skills and expanded their income in Okija. Other studies have also noted that sand mining is a source of income and job creation 


\section{Journal of Ecology and Natural Resources}

$[40,38]$.

\section{Quantifying Sand Material Extracted from Ulashi River and Its Effects}

It was noted that over 100 trucks of sands were extracted and transported from Ulashi River monthly (Table 3). This showed that large volumes of sand resources are mined to meet up with the community's teeming demands. However, observations during mining operations both at the riverbank and on lands showed that these activities are carried out without regard to environmental sustainability and conservation strategies. This process destroyed vegetation, trees and plants and lands were degraded as well since the vegetation had to be cleared before access to the sands was be granted.

The estimated volume of extracted sands from Ulashi River was determined by finding the volume (Figure 4) of the total trips of sands removed using the measured dimensions of a typical truck used in transporting extracted sand from the river. One hundred (100) truckloads of sand were extracted monthly (Table 3).

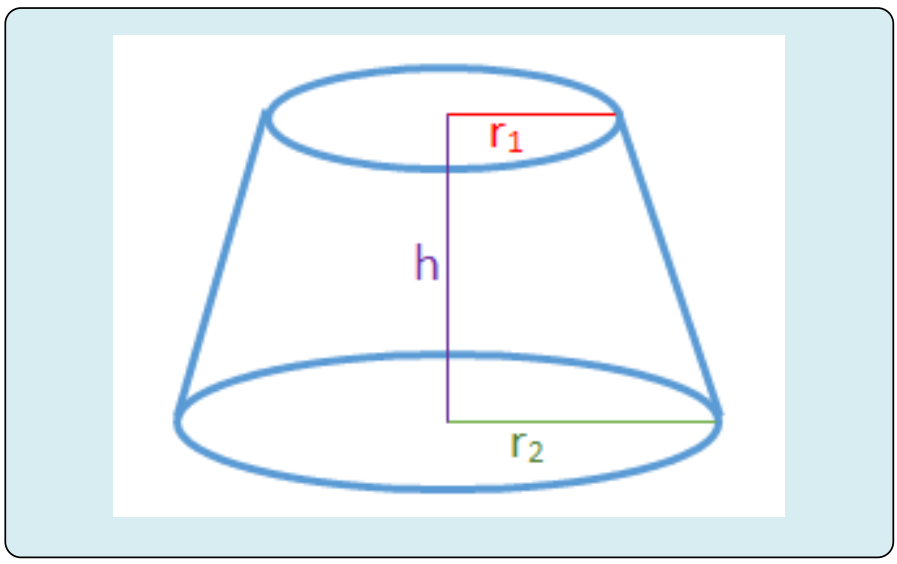

The dimensions of a sand loader used to quantify the volumes of sand extracted

The volume of one trip of sand was calculated using the formula;

$$
\text { Volume of Dumper }=\mathrm{L} \times \mathrm{B} \times \mathrm{H}
$$

Where $\mathrm{l}_{1}, \mathrm{l}_{2}=6 \mathrm{~m}$ and $5.5 \mathrm{~m}, \mathrm{~B}=1.7 \mathrm{~m}$ and $\mathrm{H}=2 \mathrm{~m}$. $\mathrm{L}=\mathrm{l}_{1}+\mathrm{l}_{2} / 2=6+5.5 / 2=$

$11.5 \times 1.7 \times 2 / 2=19.55 \mathrm{~m}^{3}$ (for one trip of sand)

For 100 trips of sand for 17 years is $100 \times 19.55 \times 17=$ $33,235 \mathrm{~m}^{3}$

It was estimated from the study that $33,235 \mathrm{~m}^{3}$ of sands have been removed from Ulashi River for the past 17 years.
In addition, this estimate considered only sands extracted from the Ulashi River and transported monthly by loaders within the past 17years, other surplus clandestine sands mined using buckets, barrows and other mediums were not included in this analysis. It is expedient to note that interviewed respondents gave varied responses over the exact time river mining commenced. The key informants indicated that river mining was a prevalent culture in Okija since the existence of the Ulashi River; hence, 17 years was used in accordance to Mbajiorgu [20] who indicated that sand mining at Ulashi River bank has been on-going for more than seventeen (17) years.

This result showed that over the years, a quantifiable amount of sand has been extracted from the Ulashi River. Large withdrawals of sands from river banks lowered the water levels (Figure 6) and depreciated the river bank and channel degradation. This exposed large -scale removal of river sediments, erosion at the river bank, digging below the existing riverbed and changing the channel bed. These findings was supported by Lai, et al. where sands lost from the Poyang Lake in China yearly had an estimated volume of 236 million cubic meters. Poyang Lake has five rivers flowing into it and a catchment area of 162,225square kilometres, a maximum length of 170 kilometres and 1,200kilometers shore length. Obviously, it is a larger water body compared to Ulashi River; nevertheless, this showed that irrespective of the river size, mined river sands depreciate sands from riverbed. Another study by Yen and Rohasliney [41] also corroborated the findings in this present study noting that sand mining negatively affected the river system in Malaysia. Further observations during the study showed that river mining in Ulashi River was carried out with the aid of a dredging machine (Figure 5) which is used to gouge sands from the river bank. The community miners also extracted sands with the aid of shovels and wheelbarrows (Figure 6) most times professional divers used buckets to scoop sands from the river bed as well.

Other sources of river contamination during in-stream mining can be through the release spills and leakages from excavation machinery during mining/transportation vehicles thereby compromising the water quality. Also, during rain fall, particles were also transported from mined areas on land and washed downstream into the river modifying the hydrologic condition which can affect river plants and aquatic life and also the river speed, volume and the bank of the river [42]. The turbidity levels of the Ulashi River have been altered as a result of high river siltation levels (Figure 7) thereby fisheries and other aquatic organisms domiciled in it are endangered.

The increased turbidity levels may hinder the penetration of direct sunlight thereby inhibiting the process 
Journal of Ecology and Natural Resources

of photosynthesis. High turbidity levels can indirectly affect the ability of aquatic life from water transparency and its capacity to feed, breath and reproduce [43]. A key informant who was formerly a fisherman showed his concern on how sand mining affected his fishing business, in his own words: My fish business was doing well before sand mining at the river became intense, based on that sands are collected on a daily basis. The quantity of fishes I caught reduced and most of them were dying, others swimming far away beyond the normal place I fix my nets. I spend longer hours fishing and yet, many times I come back with nothing to sell or feed my family. The river is disturbed by sand mining so fishes can no longer stay long and live.

This is an indication that river sand mining has an adverse effect on aquatic life and livelihood of the residents. A similar report given by Tamuno [44] agreed that the depth of the dredged river sections poses additional risk to fishermen and other river users. Adesina, et al. [45] also concurred that sand mining makes the sand bed deeper, which leads to increased depth of water bodies and its ultimate effect is reduction of income for fishermen because less quantities of fish will be caught.
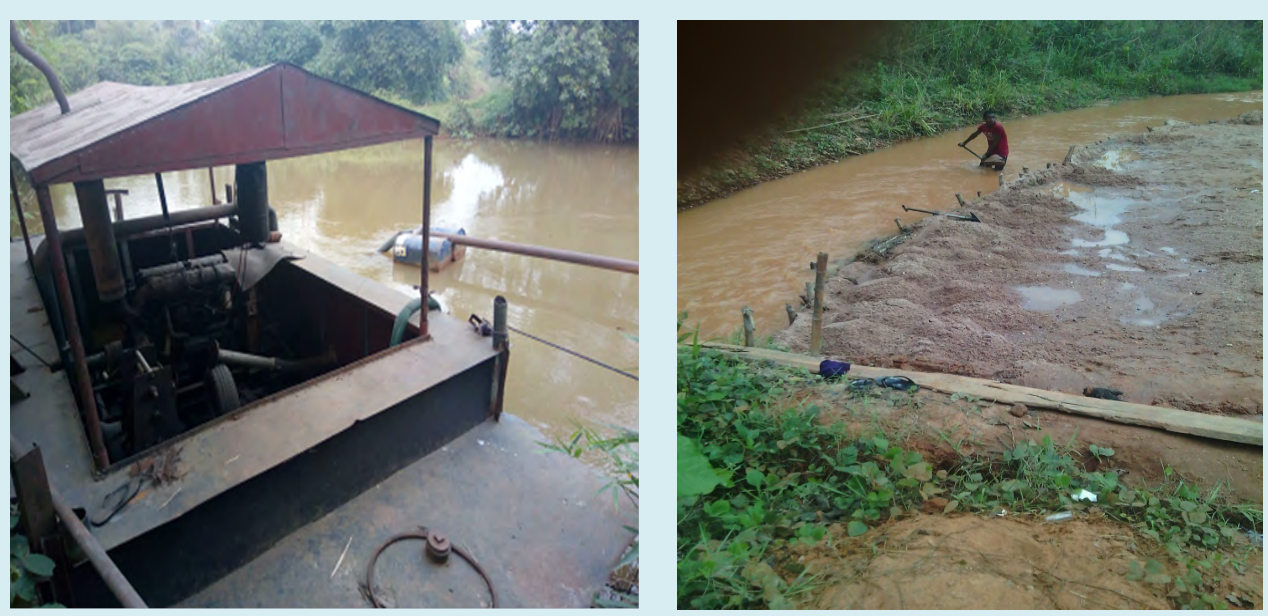

Figure 5: Showing sand mining at the two sampling points of maximum sand mining at Urashi River using a dredging machine and manual hand digging by miners.

Source: Fieldwork, 2020.
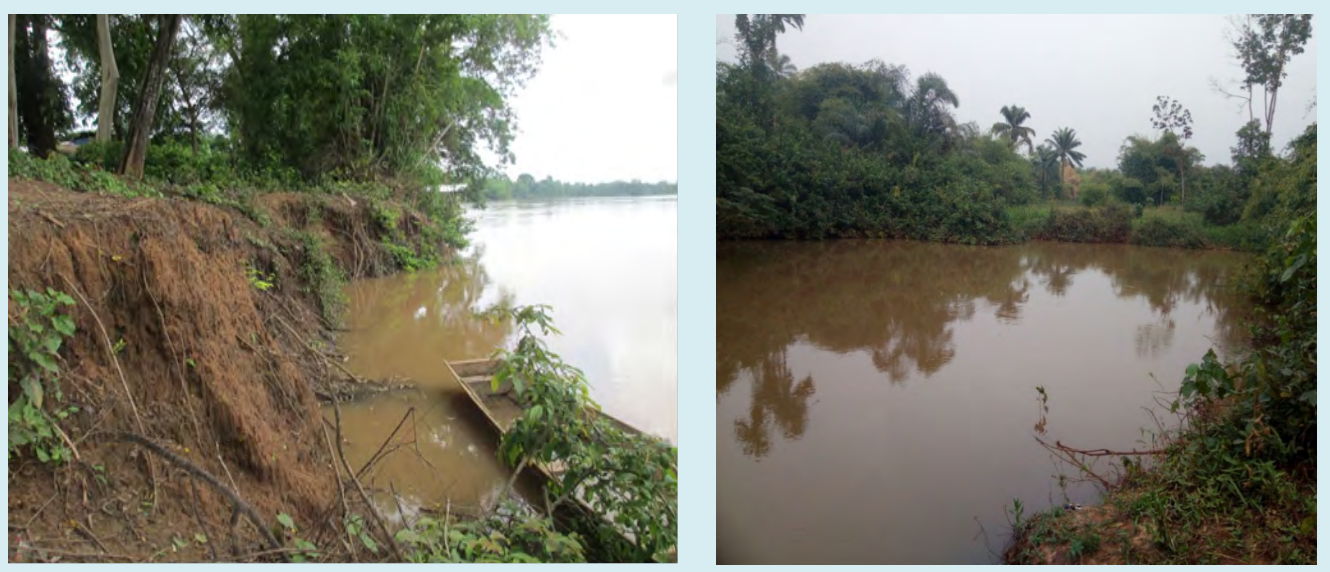

Figure 6: Showing erosion and a lowered river bed and also upstream course of Urashi River off the sand mining activities where control sample was taken.

Source: Fieldwork, 2020 


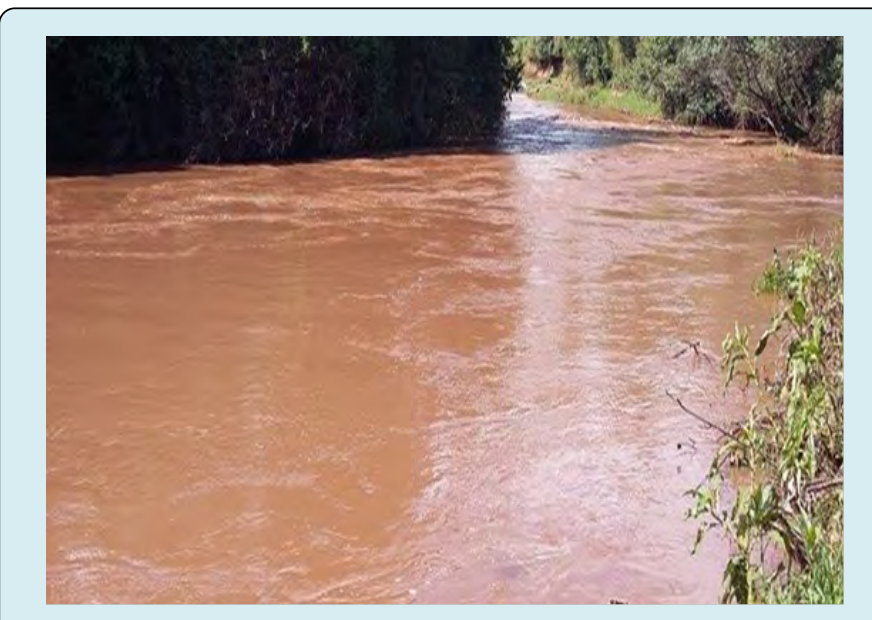

Figure 7: Showing river siltation immediately after sand extraction.

Source: Fieldwork, 2020

\section{Effects of Sand Mining on the Environment}

The open-pit mining approach was adopted by miners in the study area. This approach is considered as one of the most dangerous means of resource extraction based on its significant damage to ecology, vegetation and miners' health [46]. This technique is mostly unregulated and environmentally unfriendly with the absence of a scientific approach. It requires the deforestation and removal of substratum materials which affects arable lands, vegetation and trees degrading the landscape [46].

More so, deforestation of trees and forest areas are instrumental to global warming and heightened climate crisis. Since, trees which serve as carbon sinks, when destroyed are unable to balance between the uptake and the release of carbon [47]. In addition, animals are dislocated from their habitat examples are Snakes, birds, insects, lizards, squirrels, grass cutters, among others. Some of the plants and animals could be totally lost through death or extinction based on the fact that most of them cannot survive elsewhere. Also, the soil in the study area is a habitat for some micro-organisms (soil microbes) such as fungi, bacteria, protozoa, algae, etc. these micro-organisms can die as the soil in which they live have been disturbed thus leading to loss of biodiversity in the study area [48].

The mining of sand in Okija involved the use of excavators, loaders, shovels and other machines which disrupts the lands leaving heaps of overburden. Sand mining pollutes the atmosphere through noise and release of particulate matter that does not only discomfort residents through constant traffic and noise, but clouds of dust particles cause significant damage to air quality [49]. Unfortunately, the sand workers do not use any means of protection or mask for their health. Also, vast arable lands, economic trees that were destroyed include kola nut, Berry, Pea, Shea-butter, Palm trees and unquantifiable plant species (Figure 8). A study made by Akanwa, [50] agreed that mining has led to the loss of economic trees, farmlands and vegetation in Ozubulu, Anambra State, Nigeria. Also, studies made by Kitula and [51] supported that sand mining has brought about soil degradation, loss of livestock and disruption of wildlife and increased number of patients with respiratory illness.

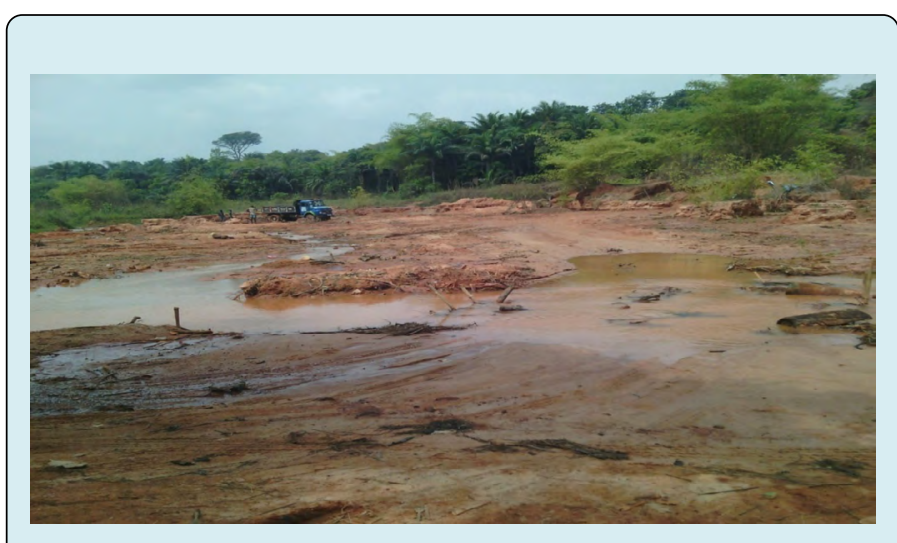

Figure 8: Showing large expanse of lands that vegetation and trees have been destroyed and gullies filled with water. Source: Fieldwork, 2020

\section{Ulashi River Quality and Aquatic life/Public Health Risks}

(Table 7) summaries the physical and chemical parameters from the three sampling points along Ulasi River. The percentage compliance test with regulatory standards was performed for the water samples of the Urashi River. The NESRA and WHO guidelines for permissible limit was used for comparative compliance tests, to determine the relative pollution level of the water samples. The sample $\mathrm{pH}$ range for sample 1 and 2 were acidic while the control was in accordance with the permissible standard. The turbidity of samples 1 and 2 showed that all the samples were above the acceptable NESERA standard. The total dissolved solids (TDS) values were all within the acceptable standards. The total soluble solids (TSS), COD and conductivity levels were all in accordance to the standards. The dissolved solids (DO) of both samples 1 and 2 were high while the control was within the acceptable limits. The BOD values exceeded the acceptable standard for all the samples 1 and 2 while the control was insignificant. 
Journal of Ecology and Natural Resources

\begin{tabular}{|c|c|c|c|c|c|}
\hline Parameters & Sample 3 & Sample 1 & Sample 2 & WHO Standard & NESERA Standard \\
\hline $\mathrm{pH}$ & 6.4 & 5.78 & 5.84 & $6.5-8.5$ & 06-Sep \\
\hline Turbidity (NTU) & 14.2 & 15.9 & 14.3 & 5 & 5 \\
\hline TDS (mg/l) & 2 & 2.6 & 2.6 & 500 & 500 \\
\hline TSS (mg/l) & 2.8 & 3.3 & 3.2 & 50 & 30 \\
\hline Conductivity $(\mu \mathrm{s} / \mathrm{cm})$ & 21.7 & 38.2 & 22.1 & 1000 & 500 \\
\hline DO (mg/l) & 5.2 & 11 & 5.7 & 10 & 7 \\
\hline $\mathrm{COD}(\mathrm{mg} / \mathrm{l})$ & 160 & 229.3 & 245.3 & 100 & 100 \\
\hline BOD & 40 & 240 & 119 & 5 & 5 \\
\hline Chloride (mg/l) & 7 & 6 & 4 & 250 & 200 \\
\hline $\mathrm{Pb}^{2+}(\mathrm{ppm})$ & 0.136 & 0.162 & 0.154 & 0.001 & 0.001 \\
\hline $\mathrm{Zn}^{2+}(\mathrm{ppm})$ & 0.071 & 0.113 & 0.113 & 0.05 & 0.03 \\
\hline Nitrate $(\mathrm{mg} / \mathrm{l})$ & 8.227 & 8.886 & 8.45 & 10 & 10 \\
\hline Fluoride $(\mathrm{mg} / \mathrm{l})$ & 0.102 & 0.204 & 0.133 & 2 & 1.5 \\
\hline Manganese (ppm) & 0.315 & 0.666 & 0.024 & 0.05 & 0.05 \\
\hline Sulphate (mg/l) & 95.88 & 92.587 & 83.946 & 250 & 200 \\
\hline
\end{tabular}

Table 7: Result of Physiochemical Analysis.

Source: Fieldwork, 2020

The sampled chemical parameters revealed that Chlorine, Fluoride and Sulphate for both samples 1 and 2 and control values were all in accordance with the standard for water quality in Nigeria. Nitrate values of samples $1 \& 2$ and control revealed they were all above the NESERA standard. The samples of heavy metals $\mathrm{Zn}, \mathrm{Pb}$ and $\mathrm{Mn}$ were analysed. The results showed that all values of $\mathrm{Zn}, \mathrm{Pb}$ and $\mathrm{Mn}$ were slightly above the permissible limits.

The results of Table 7 showed that there are variations in the physical parameters and heavy metals. The $\mathrm{pH}$ values for both sampling points were acidic. This showed that sand mining operations overtime have affected the quality of the river. The control sample was within the acceptable standards. The $\mathrm{pH}$ of water affects the solubility of many toxic and nutritive chemicals, implying that their presence can be toxic to aquatic organisms. Results showed that Dissolved Oxygen (DO) values $(11 \mathrm{mg} / \mathrm{l})$ of sample 1 exceeded the acceptable standards of $(10 \mathrm{mg} / \mathrm{l})$. Sample 2 and control were at normal levels. This indicated that the aquatic life is endangered and may result to large fish kills as concentration is increased. The value of Chemical Oxygen content (COD) is an indication of the content of degradable organic and inorganic matter, expressed by the amount of oxygen required for the degradation process. The result showed that the COD values for sample $1(229.3 \mathrm{mg} / \mathrm{l})$ and sample $2(245.3 \mathrm{mg} / \mathrm{l})$ and control sample $(160 \mathrm{mg} / \mathrm{l})$ all exceeded the acceptable standard for NERESA/WHO. This showed that there are increased organic contaminants present in the river confirming that sand mining has affected the water quality at both downstream and has spread even to the upstream point.

The BOD is an indication of the amount of oxygen required for microorganisms to biologically decompose organic materials. The values of BOD exceeded the acceptable standards with sample 1 and 2 while control was within limits. The high BOD level is an indication that there is accelerated bacterial growth which is detrimental to available oxygen levels putting the aquatic life-fishes, river plants in danger in Ulashi River. This implied that the aquatic health and life will diminish as oxygen levels are consumed. Clearly, the levels of BOD and COD are expedient for the amount of oxygen used to oxidize the substances in Ulashi River. This is supported by Juniah, et al. [52]. The study stated that Lambidaro River had high pollution index based on the sand mining activities in Indonesia.

Turbidity occurs when there are particles in the water that absorb light and cause backscattering [43]. Results also indicated that the turbidity levels for sample 1 and 2 exceeded the permissible standards while the value for the control sample was insignificant. This confirmed the physical disturbance of the sediment while dredging the sand affects the suspended solids thereby increasing turbidity of the water.

Additionally, other parameters measured for this study 


\section{Journal of Ecology and Natural Resources}

such as TDS, TSS, Conductivity, Chlorine, Fluoride, Nitrate and Sulphate levels were insignificant compared to the permissible limits of NESERA/WHO. The heavy metals all indicated variation in their concentration levels. $\mathrm{Pb}$ levels exceeded the acceptable levels for sample 1, 2 and 3 (control sample) against the acceptable standard. The high levels of lead indicated in the Ulashi River may have toxic effect on the aquatic ecosystem and the health of the rural dwellers that use the river water directly for domestic purposes without treatment.

The results also showed that $\mathrm{Zn}$ values all exceeded the permissible limits for all samples. It is revealed that sample 1,2 and 3 were above the limits. High levels of zinc can have health problems such as poisoning, nausea, vomiting and Diahorea among others [53]. The results further showed that Manganese (Mn) samples 1and 2 exceeded the permissible limits while the value of control sample was insignificant. High Mn values can stain fabric with dark brown or black stains formed due to oxidation of Manganese and its health effects are not a concern until concentrations are appropriately ten times higher [54].

The compliance level of these parameters as shown in Table 7, clearly confirmed variations levels in physical parameters such as $\mathrm{pH}$, turbidity, DO, COD, BOD and heavy metals $\mathrm{Pb}, \mathrm{Zn}$ and $\mathrm{Mn}$. It was also indicated that Sample 1 had higher pollution levels than sample 2 . This may be because of its proximity to the riverbank where sand mining is intense. However, it can be seen from the results of sample 2 that the pollution loads were equally significant. More so, it was seen that the pollution loads has also spread across to the upstream where there are no active sand mining actions (where the control sample was taken) with slightly high variations in turbidity, COD levels and all the heavy metals. This increase to non-mining areas is explained by Hitchcock, et al. [55] and Gubbay, [56] both noted that very fine sand is dispersed by dredging may be carried up to $11 \mathrm{~km}$ from the dredging site, fine sand may be carried up to $5 \mathrm{~km}$, medium sand may be carried up to $1 \mathrm{~km}$ and coarse sand may be carried less than $50 \mathrm{~m}$. Clearly, sand mining activities have affected Ulashi River, added to its economic contributions; it also has the propensity to cause immense damage to the planetary health. This include farmlands, trees, vegetation, river system, increased particulate matter, global warming through carbon emission due to loss of trees which serve as carbon sinks and also possible health dangers on aquatic and human life in Okija.

\section{Towards Sustainable Sand Mining through Youth Intervention}

This study revealed that sand mining generates jobs and expands the income of mostly youths in the community.
The economic potentials and contribution of sand mining especially towards poverty alleviation and rural development in Okija has been noted. Also, the immense propensity of sand mining to cause damage on planetary health- vegetation, river system, and health is not hidden to create a balance between sand mining and sustainable planetary health, it is expedient that good practice be promoted. This should include environmental impact assessment. enforcement of policies, monitoring and community based research targeted towards environmental and health protection.

Moreover, this study showed that youths were greater beneficiaries to sand mining operations and Nigeria has one of the largest populations of youth in the world comprising $33,652,424$ members [57]. Hence, youth intervention can be a tool to foster sustainable development in Okija. Since, majority of the youth are involved in sand mining activities directly and indirectly. In essence, youths can propel sand mining as a means for community development.

This can be achieved firstly, by partnership between the state and local government to formalize the small scale sand mining community in okija into cooperatives with larger mineral enterprise in order to develop their capacity. Secondly, youths should be granted access to environmental education on the negative effects of sand mining on vegetation, landscape, health, climate change, biodiversity, air and noise pollution in order, to minimise degradation in the process of sand extraction thereby, protecting their lands. Thirdly, they should be given access to capital, equipment, technological assistance and also be included in community research.

Finally, sand mining should be linked more deeply into community development agenda since, it is a silent economic contributor that provides jobs especially for the youths. There are investment opportunities that abound in sand mining that still remains largely untapped in Nigeria and Africa.

\section{Conclusion}

The study discovered that the activities of sand mining have increased the economic value of the study area by providing employment opportunities, livelihood and various related skills especially for young people. This has contributed to skill acquisition and youths empowerment. However, there were notable negative effects of sand mining on the environment and Ulashi River. River sand mining has removed large quantities of sands from the river thereby, lowering the water levels and channel degradation, exposing large -scale removal of river sediments and erosion at the river bank. Ulashi River water quality has been altered, endangering fisheries and other aquatic organism and even human health. Sand mining on land has also affected the 
topsoil, trees, vegetation, and various plants.

Sand mining has caused environmental degradation on planetary health. River mining has been largely banished in most developed countries. It is of utmost importance for developing countries to embrace sustainable development and planetary health key principle which includes the integration of the environment, social, economic and human health concerns into all aspects of decision/policy making before execution of projects. Youths should be empowered (education and finance) and employed as agents of sustainable sand mining in Okija. Further, environmentally friendly measures are expedient to monitor sand mining operations through restoration of lost vegetation on lands. Also, persistent enforcement; strict fines and a constant monitoring should be carried out in sand mines to issue notices of violation. Best practices for sand mining in Okija should be pursued through planting of vegetation along stream bank to reduce erosion and maintaining a minimum 100 feet shelter zone between mines and streams and the extent of sand removal from the river bed should be estimated and monitored.

\section{References}

1. United Nations Environment Program (2014) UNEP Global Environmental Alert Services (GEAS)-sand, rarer than one thinks. Online Newsletter, Issue 3.

2. United Nations Environment Programme (UNEP) Sand, Rarer Than One Thinks. March 2014.

3. Obiadi II, Nwosu CM, Ajaegwu NE, Anakwuba EK, Onuigbo NE, et al. (2011) Gully Erosion in Anambra State, South East Nigeria: Issues and Solution. International Journal of Environmental Science 2(2): 795-804.

4. Swanson A (2015) How China Used More Cement in 3 Years Than the U.S. Did in the Entire 20th Century.

5. Beiser V (2017) Sand mining: The Global Environmental Crisis You've Probably Never Heard of. Support the Guardian.

6. (2019) GAIN-Global Aggregates Information Network. A sustainable Aggregates Industry for a sustainable Europe.

7. Hilson G (2000) Barriers to Implementing Cleaner Technologies and Cleaner Production (CP) Practices in the Mining Industry: A Case Study of the Americas. Minerals Engineering 13(7): 699-717.

8. Hilson G, McQuilken J, Perks R (2019) State of the Artisanal and Small Scale Mining Sector Report. World Bank.
9. Akanwa AO, Ikegbunam FI (2017) Natural Resource Exploitation: Consequences of Human Actions and Best Practices for Environmental Sustainability-A Review. International Journal of Multidisciplinary Research Studies 2(3): 1-14.

10. National Green Tribunal (2019) Green Court seek report on Kollam sand Mining after Kerala Girls Video, India Waterportal.

11. Pearce F (2017) How a Proposed Strip Mine Brought Conflict to South Africa's World Coast. Yale Environment.

12. McCarthy N (2014) China used more Concrete in 3 years than the US used in the entire $20^{\text {th }}$ century. Forbes.

13. Snyder M (2018) A Year after Harvey Push Expected for Stricter Regulation of sand Mining Industry. Houston Chronicle.

14. Xijun L, Shankman D, Huber C, Yesou H, Jiahu J, et al. (2014) Sand Mining and Increasing Poyang Lakes Discharge Ability: A Reassessment of for Lake Decline in China. Elsevier 519: 1698-1706.

15. Piman T, Manish S (2017) A Study on Sediment in the Mekong River Basin: Current State and Future Trends. Stockholm Environment Institute, pp: 48.

16. Nwajide CS, Reijers TJA (1996) Geology of the Southern Anambra Basin. In: Reijers TJA (Ed.), selected chapters on Geology, SPDC, Warri 2(3): 133-148.

17. National Population Commission (2006) Population Distribution by Sex, State, LGAs and Senatorial District: 2006 Census Priority Tables Abuja, Nigeria.

18. United Nations General Assembly (1987) Report of the World Commission on Environment and Development: Our Common Future. Oslo, Norway: United Nations, pp: 1-300.

19. SC Editors (1991) Planetary Health: Are we you part of the solution. Beginnings 11(1): 6 .

20. Mbajiorgu CC (2003) A Water Quality Study of Ulasi River at Selected Locations. 29 ${ }^{\text {th }}$ WEDC International Conference, towards the Millennium Development Goals.

21. Nema $O$ (2004) My Father's Village-Excerpts from a Memoir in Progress (New York).

22. Mmom PC, Alfesehi PE (2013) Impact of 2012 Flood on Water Quality and Rural Livelihood in the Orashi Province of the Niger Delta, Nigeria. Journal of Geography and Geology 5(3): 216-225. 
23. (2016) NGO Partners with Imo, Sinks Borehole in 3 Communities.

24. Ijeomah HM, Adedapo AA, Abimbola OA, Abedeen AA (2009) Urashi Waterfall Ecotourism Development and Cultural Challenges in Dikenafai, Ideato South Local Government Area, Nigeria. African Research Review 3(4): 261-274.

25. Horton R, Beaglehole R, Bonita R, Raeburn J, Mckee M, et al. (2014) From Public to Planetary Health: A manifesto. The Lancet 383(9920): 847.

26. Whitmee S, Haines A, Beyrer C, Boltz F, Capon AG, et al. (2015) Safeguarding Human Health in the Anthropocene epoch: Report of the Rockefeller Foundation-Lancet Commission on Planetary Health. The Lancet 386(1007): 1973-2028.

27. Seltenrich N (2018) Down to Earth: The Emerging Field of Planetary Health. Environ Health perspect 126(7): 072001 .

28. Brodhag C, Tailere S (2006) Sustainable Development Strategies: Tools for Policy Coherence. Natural Resources Forum 30(2): 136-145.

29. Cerin P (2006) Bringing Economic Opportunity into line with Environmental Influence: A Discussion on the Coase Theorem and the Porter and Van der Linde Hypotheses. Ecological Economics 56(2): 209-225.

30. Hancock T (1997) Ecosystem Health, Ecological Iatrogenesis and Sustainable Human Development. Ecosystem Health 3(4): 229-234.

31. Egboka BCE, Okpoko EI (1999) Conjunctive uses of water resources and management in Anambra State, Nigeria. Natural and Applied Science Journal 9(2): 2005.

32. (2012) Nigerian Meteorological Agency (NIMET), Nigerian Meteorological Agency (NIMET) 2012 seasonal rainfall prediction \& socio-economic implications for Nigeria.

33. Iwena CU (2010) Essential Geography for Senior Secondary School, $7^{\text {th }}($ edn), University Press, Ibadan, Nigeria.

34. Green S (1991) How Many Subject Does it take to do a Regression Analysis. Multivariate Behavioural Research 26(3): 499-510.

35. Pinnock H, Epiphaniou E, Taylor SJ (2014) Phase IV implementation studies: the forgotten finale to the complex intervention methodology framework. Ann. Am. Thorac. Soc. Suppl 2: S118-S122.
36. APHA (1998) Standard Methods for the Examination of Water and Wastewater, $20^{\text {th }}(\mathrm{edn})$, American Public Health Association, American Water Works Association and Water Environmental Federation, Washington DC.

37. Gathogo MP, Amimo MO (2017) Social Environmental Effects of River Sand Mining. A Case Study of Ephemeral River Kivou in Kitui County, Kenya. IQSR Journal of Humanities and Social Science 22(11): 31-37.

38. Sumani JBB (2019) Possible Environmental and SocioEconomic Ramifications of Sand and Gravel Winning in Danko, Upper West Region of Ghana, Ghana Journal of Geography 11(2): 27-51.

39. Akanwa AO, Ikegbunam FI (2017b) Environmental Crisis Associated with Sand Harvesting Activities in Awka North Settlement Area in Anambra State. International Journal of Economic Growth and Environmental Issues (EGEI) 5: 114-125.

40. Erhun MO (2015) The Contribution of the Minerals and Mining Industry to Poverty Alleviation and Sustainable Development in Nigeria. A legal Perspective. Journal of Energy Technologies and Policy 5(8): 96-109.

41. Yen TP, Rohasliney H (2013) Status of Water Quality Subject to Sand Mining in the kelantastan River, Kelantastan, Malaysian. Tropical Life Sciences Research 24(1): 19-34.

42. Rinaldi M, Wyzga B, Surian N (2005) Sediment Mining in Alluvial Channels: Physical Effects and anagement Perspectives. River Research and Applications 21(7): 805-828.

43. Supriharyono, S (2004) Effects of sand mining on coral reefs in Riau Islands. Journal of Coastal Development. 7(2): 89-103.

44. Tamuno PBL (2005) Ecolivelihood assessment of Inland River Dredging; the Kolo and Otuoke creeks, Nigeria. Loughborough University, pp: 1-328.

45. Adesina KT, Adunola AO (2017) Perceived Effects of Sand Dredging on Livelihood Diversification of Artisanal Fisher Folks in Lagos State, Nigeria. Agricultura Tropica et Subtropica, 50(2): 71-79.

46. Chena J, Lia K, Chang KJ, Sofia G, Tarolli P (2015) Openpit Mining Geomorphic Feature characterisation. International Journal of Applied Earth Observation and Geoinformation 42: 76-86.

47. Brief C (2009) Tropical Forests are No Longer Carbon Sinks because of Human Activity. 
48. da Silva EF, Bento FD, Mendes CA, da Mota GF, Silva Mota SCL, et al. (2018) Environmental impacts of sand mining in the city of Santarém, Amazon region, Northern Brazil. Environment Development Sustainability 22(1): 1-14.

49. Huertas JI, Hueras ME, Izquierdo S, Gonzaliez ED (2012) Air quality Impact Assessment of Multiple Open Pit Coal Mine in Northern Colombia. Journal of Environmental Management 93(1): 121-129.

50. Akanwa AO (2018) Effect of Clay Mining on the Quality of Eze River in Ozubulu, Anambra State. African Journal of Environmental Research 1(2): 104-117.

51. Ako AT, Onoduku US, Oke SA, Essien BI, Idris FN, et al. (2014) Environmental Effects of Sand and Gravel Mining on Land and Soil in Luku, Minna, Niger State, North Central Nigeria. J Geosci Geomat 2(2): 42-49.

52. Juniah R, Rahmi H (2017) The Influence of Sand Mining toward the Sustainability of Power Support and capacity of Lambidano river. AIP Conference Proceeding.
53. ATSDR (2005) Public Health Statement Zinc August Agency for Toxic Substances and Disease Registry. United States Dept of Health and Human Services.

54. ATSDR (2000). Toxicological profile for Manganese. Atlanta Georgia, GA, United States Dept of Health and Human Services, Agency for Toxic Substances and Diseases Registry.

55. Hitchcock DR, Drucker BR (1996) Investigation of benthic and surface plumes associated with marine aggregates mining in the United Kingdom. In: The global ocean-towards operational oceanography. Pro-ceedings of Conference on Oceanology International. Spearhead Publications, Surrey Conference Proceedings 2: 221-84.

56. Gubbay S (2003) Marine, aggregate extraction and biodiversity, Wildlife Trusts, WWF-UK, UK.

57. Nigeria Youth Policy (2009) Second National Youth Policy Document of the Federal Republic of Nigeria 2009, pp: 2-80. 